\title{
Udział podmiotów ekonomii społecznej w zamówieniach publicznych
}

\section{Dorota Moroń*}

Streszczenie: Podmioty ekonomii społecznej najczęściej prowadzą działalność gospodarczą, pozyskując w ten sposób środki, które mogą być przeznaczane na bieżące funkcjonowanie przedsiębiorstwa i realizację celów społecznych. Celem artykułu jest analiza udziału podmiotów ekonomii społecznej w postępowaniach o udzielenie zamówienia publicznego jako jednej z form pozyskiwania zleceń w ramach prowadzonej działalności gospodarczej. Zaprezentowano w nim wyniki badań empirycznych $w$ tym zakresie. $W$ artykule wykorzystano metodę desk research oraz metodę statystyczną w ujęciu ilościowym. Przeprowadzone badania wykazały, że większość podmiotów ekonomii społecznej nie jest zainteresowanych zamówieniami publicznymi i nie bierze udziału w postępowaniach o udzielenie zamówienia publicznego. Jednocześnie niektóre podmioty ekonomii społecznej z powodzeniem wykorzystują takie działania, co pozwala na wskazanie, że zamówienia publiczne mogą stanowić atrakcyjną formę pozyskiwania zleceń.

Słowa kluczowe: podmioty ekonomii społecznej, działalność gospodarcza, zamówienia publiczne, klauzule spoteczne.

\section{Wprowadzenie}

Specyficzny charakter podmiotów ekonomii społecznej (PES) wynika z faktu, iż łączą one cele ekonomiczne z celami społecznymi - prowadzą działalność gospodarczą, ale orientują się na społecznie użyteczne cele, którymi mogą być m.in. dostarczanie usług społecznych, rozwiązywanie problemów społecznych czy reintegracja społeczna i zawodowa osób zagrożonych marginalizacją. Innymi słowy podmioty ekonomii społecznej nakierowane są na społeczną misję, co umożliwia uzyskanie społecznie pożądanej wartości [Pacut, 2015].

W szerokim ujęciu do podmiotów ekonomii społecznej zaliczamy m.in. przedsiębiorstwa społeczne, w tym spółdzielnie socjalne, podmioty reintegracyjne, organizacje pozarządowe, spółdzielnie, których celem jest zatrudnienie czy spółki non-profit [MPiPS, 2014, s. 15-16; Minister Rozwoju i Finansów, 2016, s. 10-11]. W przypadku wielu z tych podmiotów społeczna misja wysuwa się na plan pierwszy, jednakże istotny jest fakt, że dla sporej części z nich - szczególnie tych, określanych mianem przedsiębiorstw społecznych [MPiPS, 2014, s. 16] - istotne jest prowadzenie działalności gospodarczej opartej o ryzyko ekonomiczne. Działalność gospodarcza umożliwia realizację celów reintegracji społecznej i zawodowej - przede wszystkim dzięki zatrudnianiu osób należących do kategorii zagrożonych wykluczeniem - oraz innych celów społecznych, jak np. świadczenie usług zaspokajających istotne społecznie potrzeby (m.in. opiekuńczych, socjalnych) czy przeznaczanie zysków z działalności gospodarczej na cele społecznie użyteczne [Batko, Bogacz-Wojtanowska, 2015; Zboroń, 2015;

\footnotetext{
* Dorota Moroń

Instytut Politologii

Uniwersytet Wrocławski

ul. Koszarowa 3, bud. 2/3, 51-149 Wrocław

e-mail: dorota.moron@uwr.edu.pl
} 
Schimanek, 2015; Chomątowska, 2014]. Podmioty ekonomii społecznej korzystają z wielu różnych źródeł pozyskiwania środków finansowych, a działalność gospodarcza często nie jest kluczowym z nich, szczególnie w przypadku organizacji pozarządowych [Schimanek, 2015]. Jednocześnie w przypadku przedsiębiorstw społecznych powinna ona stanowić podstawową formę działalności.

W ramach prowadzonej działalności podmioty ekonomii społecznej mogą korzystać z różnych form pozyskiwania zleceń - zarówno od osób fizycznych, jak i podmiotów prawnych, w tym instytucji publicznych. W tym ostatnim przypadku istotne znaczenie mają zamówienia publiczne i dotacje na realizację zadań publicznych, w tym finansowanych ze środków krajowych, jak i europejskich [Schimanek, 2015]. Udział w postępowaniach o udzielenie zamówienia publicznego, ogłaszanych przez instytucje publiczne, zarówno administrację rządową, jak i samorządową, jest jedną z istotnych form pozyskiwania zleceń przez przedsiębiorstwa i może być wykorzystywany także przez podmioty ekonomii społecznej.

Celem artykułu jest analiza udziału podmiotów ekonomii społecznej w postępowaniach o udzielenie zamówienia publicznego jako jednej z form pozyskiwania zleceń w ramach prowadzonej działalności gospodarczej. Przedstawiono w nim, w oparciu o badania empiryczne, weryfikację hipotezy zakładającej, iż większość podmiotów ekonomii społecznej nie jest zainteresowanych zamówieniami publicznymi i nie bierze udziału w postępowaniach o udzielenie zamówienia publicznego. W artykule wskazano na przyczyny tego zjawiska i sformułowano rekomendacje w zakresie wsparcia udziału podmiotów ekonomii społecznej w zamówieniach publicznych. Podjęcie tego tematu ma istotne znaczenie ze względu na brak w literaturze naukowej kompleksowych badań i analiz wskazujących na udział podmiotów ekonomii społecznej w postępowa- niach o udzielenie zamówienia publicznego [Schimanek, 2015].

W artykule wykorzystano metodę analizy instytucjonalno-prawnej, metodę desk research, w ramach której dokonano analizy materiałów źródłowych oraz metodę statystyczną w ujęciu ilościowym. Badanie empiryczne, którego wyniki zostały tu zaprezentowane, zostało przeprowadzone $\mathrm{w}$ ramach projektu Skuteczni w zamówieniach publicznych, realizowanego przez Fundację "Merkury" z Wałbrzycha, we współpracy z partnerami: Opolskim Centrum Organizacji Pozarządowych z Opola, Związkiem Lubuskich Organizacji Pozarządowych z Zielonej Góry oraz Stowarzyszeniem na Rzecz Spółdzielni Socjalnych z Poznania. Projekt był finansowany ze środków Europejskiego Funduszu Społecznego, w ramach Programu Operacyjnego Wiedza Edukacja Rozwój, działania 2.9. Rozwój ekonomii społecznej (nr projektu: POWR.02.09. 00-00-0030/16) [Moroń, 2017]. Badanie przeprowadzono w terminie lipiec-wrzesień 2017 r. techniką ankiety wśród podmiotów reprezentujących pięć form prawnych PES: stowarzyszenia prowadzące działalność gospodarczą, fundacje prowadzące działalność gospodarczą, spółdzielnie socjalne, centra integracji społecznej (CIS) oraz zakłady aktywności zawodowej (ZAZ) z województw: dolnośląskiego, lubuskiego, opolskiego i wielkopolskiego. Na dzień 30 czerwca 2017 r. na terenie wskazanych województw zidentyfikowano 3055 PES, w tym 1086 stowarzyszeń prowadzących działalność gospodarczą, 1559 fundacji prowadzących działalność gospodarczą, 332 spółdzielnie socjalne, 60 CIS-ów oraz 18 ZAZ-ów. Zastosowano dobór kwotowy z podziałem kwot według form prawnych, z uwzględnieniem wielkości próby dla 95\% poziomu ufności oraz zastosowaniem doboru wyczerpującego dla dwóch kwot CIS i ZAZ, ze względu na małą liczebność tych frakcji $w$ populacji. $W$ rezultacie przebadano 386 podmiotów. Badanie nie jest reprezentatywne dla całego sektora ekonomii społecznej 
w kraju, wnosi jednak wkład w wiedzę dotyczącą wykorzystywania zamówień publicznych jako formy uzyskiwania zleceń przez PES i pozwala na wskazanie dalszych kierunków rozwoju wsparcia ekonomii społecznej.

\section{Udział podmiotów ekonomii społecznej w zamówieniach publicznych}

Realizacja zleceń uzyskiwanych od sektora publicznego jest jednym z obszarów działalności podmiotów gospodarczych. Pojawia się w tym kontekście pytanie czy zamówienia publiczne są formą pozyskiwania zleceń także przez podmioty ekonomii społecznej, czy PES wykorzystują taką możliwość i konkurują o zlecenia publiczne z tradycyjnymi podmiotami gospodarczymi.

W oparciu o wyniki przeprowadzonego badania wskazać należy, że udział w postępowaniach o udzielenie zamówienia publicznego nie jest dla podmiotów ekonomii społecznej istotną formą pozyskiwania zleceń. W postępowaniach takich udział zadeklarowało tylko 80 podmiotów, a więc 20,7\% badanych PES. Aż 306 PES, czyli 79,3\%, nigdy nie uczestniczyło $\mathrm{w}$ postępowaniach. Wskazuje to wyraźnie na fakt, że podmioty ekonomii społecznej poszukują zleceń na inne sposoby, a udział w zamówieniach stanowi rzadko wykorzystywaną formę ich uzyskiwania.

Przeprowadzona analiza pozwala na wykazanie, że na udział w zamówieniach wpływ ma forma prawna PES, fakt zatrudnienia płatnego personelu oraz branża prowadzonej działalności. Wyniki badań wskazują, że centra integracji społecznej, zakłady aktywności zawodowej i spółdzielnie socjalne biorą w postępowaniach udział znacznie częściej niż stowarzyszenia i fundacje prowadzące działalność gospodarczą (rys. 1). Wiąże się to z innym profilem działalności stowarzyszeń i fundacji oraz PES nastawionych stricte na społeczną i zawodową reintegrację kategorii zagrożonych wykluczeniem. Dla stowarzy- szeń i fundacji działalność gospodarcza ma charakter pomocniczy, uzupełniający wobec działalności statutowej i w założeniu nie powinna dominować nad działalnością non-profit [Schimanek, 2015]. Stąd prawdopodobnie wynika rzadsze wykorzystywanie mechanizmów gospodarczych. W swojej działalności statutowej stowarzyszenia i fundacje częściej angażują się natomiast w inne formy pozyskiwania środków finansowych i zleceń, głównie w oparciu o zlecanie zadań publicznych na mocy ustawy z 24 kwietnia 2003 r. o działalności pożytku publicznego i o wolontariacie. Podmioty ekonomii społecznej, które są nastawione na integrację zawodową i społeczną osób zagrożonych wykluczeniem poprzez zatrudnianie ich w ramach prowadzonej działalności gospodarczej oraz udzielanie wsparcia społecznego, jak spółdzielnie socjalne, CIS-y i ZAZ-y w większym zakresie dążą do pozyskiwania zleceń pozwalających na uzyskiwanie dochodów z działalności gospodarczej. Muszą one bowiem zapewnić - zgodnie z rachunkiem ekonomicznym - możliwość zatrudnienia osób w trudnych sytuacjach życiowych, a także personelu wspomagającego. Duże zlecenia gwarantują tym przedsiębiorstwom możliwość nieprzerwanego prowadzenia działalności i utrzymania stabilności zatrudnienia.

Udział w postępowaniach częściej biorą te PES, które mają etatowych pracowników, co wiąże się z nakładem pracy związanym z tymi działaniami (rys. 2.). Już kilkoro opłacanych pracowników zwiększa zaangażowanie w udział w procedurach pozyskiwania zleceń publicznych. Dla udziału w postępowaniach etatowi pracownicy generalnie są niezbędni, konieczne jest bowiem wyszukanie informacji o zamówieniach, przygotowanie i złożenie oferty, a następnie - w przypadku uzyskania zlecenia - zagwarantowanie realizacji zadania. Jednocześnie fakt posiadania pracowników, którym trzeba zapewnić pracę i wynagrodzenie, zmusza PES do szukania zleceń, które zapewnią odpowiedni poziom przychodów. 
Rysunek 1. Udział PES biorących udział w postępowaniach o udzielenie zamówienia publicznego w ogólnej liczbie PES wg formy prawnej PES $(n=386)$

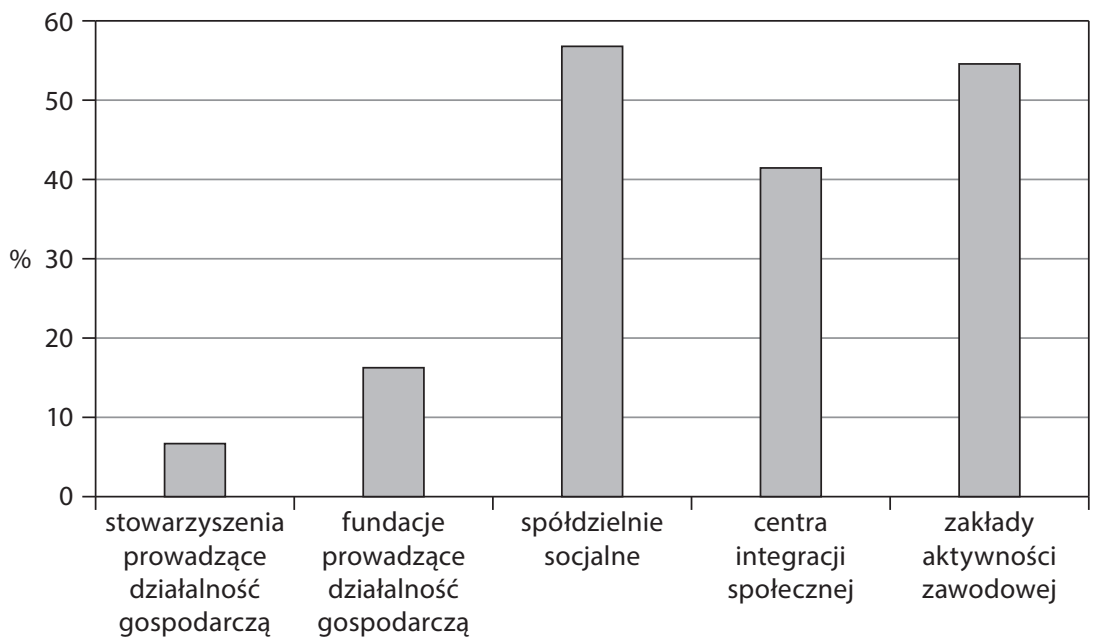

Źródło: badania własne.

Rysunek 2. Udział PES biorących udział w postępowaniach o udzielenie zamówienia publicznego w ogólnej liczbie PES wg liczby pracowników zatrudnionych na umowę o pracę w przeliczeniu na pełne etaty na 31 grudnia 2016 r. $(n=386)$

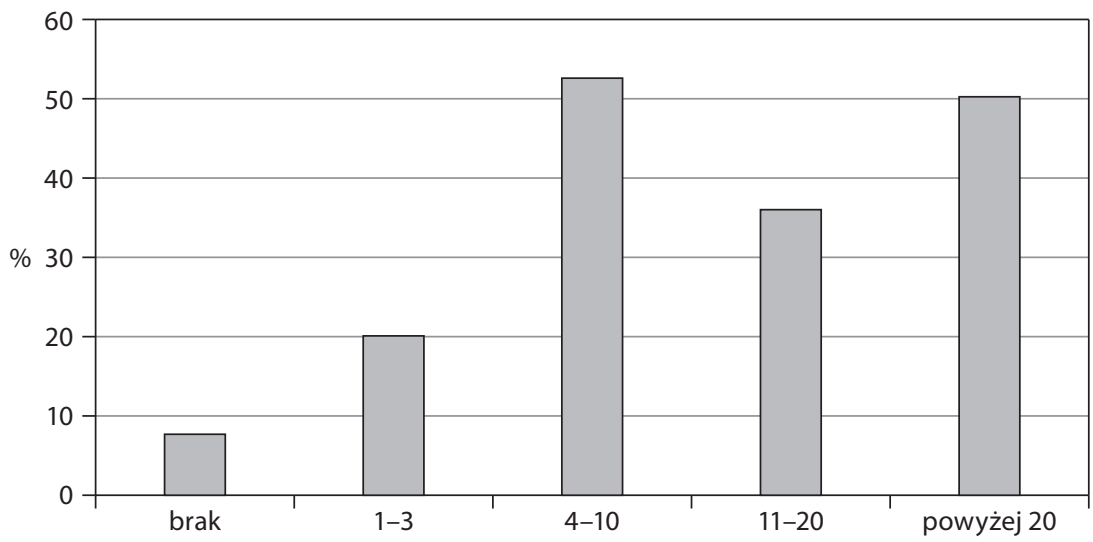

Źródło: badania własne.

Różnice jeśli chodzi o udział w zamówieniach publicznych można też odnotować patrząc na branże działalności wg sekcji PKD. Warto zauważyć, że w postępowaniach częściej brały udział podmioty prowadzące działalność wielobranżową oraz działające w obszarach takich jak:
- administracja publiczna i obrona narodowa, obowiązkowe zabezpieczenia społeczne;

- działalność w zakresie usług administrowania i działalność wspierająca;

- budownictwo; 
- handel hurtowy i detaliczny, naprawa pojazdów samochodowych, włączając motocykle;
- działalność związana z zakwaterowaniem i usługami gastronomicznymi (rys. 3).

\section{Rysunek 3. Udział PES w postępowaniach o udzielenie zamówienia publicznego wg sekcji PKD głównej działalności $(n=386)$}

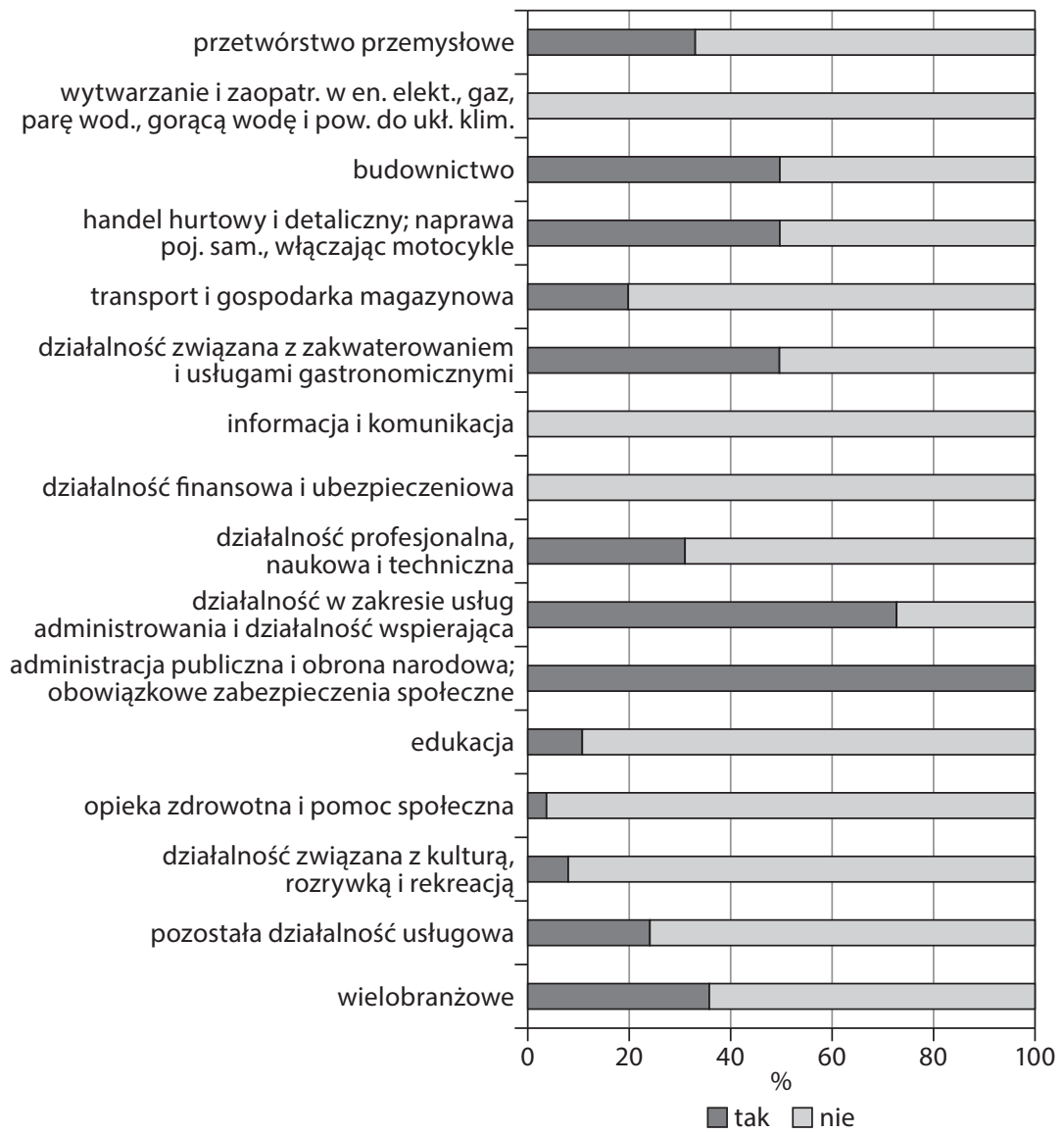

Wiąże się to również z faktem, że sektor publiczny zleca wykonanie usług czy robót w tych właśnie sferach. Podmioty ekonomii społecznej biorące udział w zamówieniach publicznych najczęściej w ramach prowadzonej działalności zajmowały się utrzymaniem porządku w budynkach, sprzątaniem i zagospodarowaniem terenów zieleni, gastronomią, usługami remontowo-budowlanymi, usługami społecznymi (głównie opiekuń- czymi) i ochroną środowiska. Są to właśnie obszary, w których samorządy zlecają usługi publiczne, dzięki czemu PES mają szanse na uzyskanie zleceń.

Obszary działań PES takie jak: opieka zdrowotna i pomoc społeczna, edukacja, kultura, rozrywka i rekreacja należą do ważnych sfer działalności pożytku publicznego, stąd prawdopodobnie podmioty uzyskują w tym przypadku zlecenia w oparciu o ustawę z 24 kwiet- 
nia 2003 r. o działalności pożytku publicznego i o wolontariacie, a w mniejszym zakresie korzystają z zamówień publicznych.

Na udział w zamówieniach publicznych nie miało wpływu województwo, w którym siedzibę miał podmiot ekonomii społecznej. Jest to istotna informacja. W oparciu o nią można przypuszczać, że podobne zaangażowanie w udział w postępowaniach o udzielenie zamówienia będzie dotyczyło PES również w pozostałych częściach kraju.

Aktywność w sferze zamówień nie zależała też od wieku podmiotu ekonomii społecznej. Zarówno młode PES, jak i te, które działają już wiele lat, wykazywały podobny zakres zaangażowania.

Widać więc wyraźnie, że tylko niewielka część podmiotów ekonomii społecznej korzysta z możliwości pozyskiwania zleceń w wyniku postępowań o udzielenie zamówienia publicznego. Wymaga to odpowiedniego przygotowania oferty i udziału w postępowaniu, które nie musi zakończyć się sukcesem dla PES. Zdecydowanie częściej z tej formy pozyskiwania zleceń korzystają podmioty zajmujące się społeczną i zawodową reintegracją osób zagrożonych wykluczeniem, które zatrudniają pracowników (w tym osoby wymagające włączenia społecznego), działające w obszarach, w których istnieją szanse uzyskania zleceń. Udział w zamówieniach publicznych może więc być - przynajmniej dla niektórych kategorii PES - szansą na realizację misji sektora ekonomii społecznej.

\section{Charakterystyka udziału PES w zamówieniach i ich skuteczność w uzyskiwaniu zleceń}

Analizując udział podmiotów ekonomii społecznej w postępowaniach o udzielenie zamówienia publicznego warto sprawdzić, jak często podmioty korzystają z tej formy i jaka jest skuteczność ich działań.

\section{Rysunek 4. Liczba postępowań o udzielenie zamówienia publicznego, w których brały} udział poszczególne podmioty ekonomii społecznej $(n=80)$

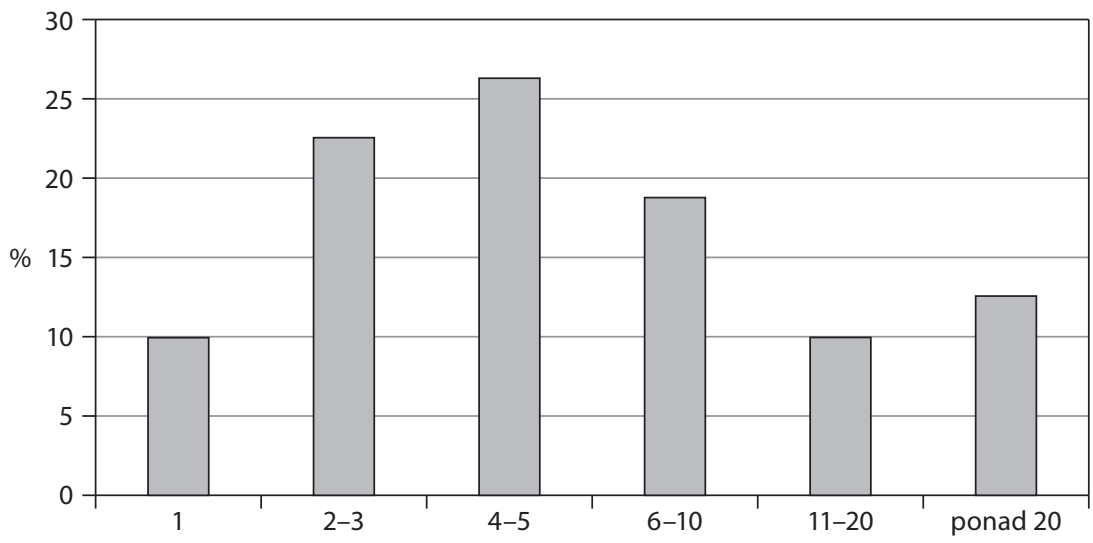

Źródło: badania własne.

Badane PES najczęściej brały udział w kilku postępowaniach, tylko 10 PES, a więc $12,5 \%$ spośród aktywnych w sferze zamówień, robiło to więcej niż 20 razy (rys. 4.). Niewiele podmiotów aktywnie próbuje pozyskiwać zamówie- nia publiczne, a dodatkowo dla większości z tych, które biorą udział w postępowaniach, stanowi to jedną z form pozyskiwania zleceń, z której korzystają stosunkowo rzadko. Udział w kilku postępowaniach wskazuje, że 
jest to raczej dodatkowe działanie, uzupełniające normalną aktywność. Tylko niewielka część sektora ekonomii społecznej upatruje w zamówieniach publicznych stałego źródła zleceń, zapewniającego dochody umożliwiające działalność i realizację społecznej misji.

62 podmioty, a więc 16,1\% ogółu badanych PES i 77,5\% tych, które kiedykolwiek uczestniczyły w postępowaniach o udzielenie zamówienia, wskazały, że brały udział w postępowaniach w latach 2015-2016. W odniesieniu do nich dokonano szczegółowej diagnozy.

W 2015 r. PES wzięły udział w 174 postępowaniach, zaś w 2016 r. już w 301 postępowaniach - obserwujemy tu znaczący wzrost liczby postępowań, w których brały udział PES - aż o 73,0\%. Średnio więc PES brały udział w 7,7 postępowaniach na przestrzeni dwóch lat.
W 2015 r. PES uzyskały 109 zamówień publicznych do realizacji, w 2016 r. było ich 154 . Widać więc również wzrost liczby uzyskanych zamówień, ale skuteczność PES w uzyskiwaniu zamówień była w 2016 r. nieco niższa niż w roku wcześniejszym - w 2016 r. sukcesem w postaci uzyskania zamówienia zakończył się dla PES udział w 51,2\% postępowań, zaś w 2015 r. udział w 62,6\% postępowań (rys. 5.). Tylko 5 spośród 62 PES biorących udział $w$ postępowaniach w tym okresie nie udało się w ogóle uzyskać zamówienia. Biorąc pod uwagę statystykę wskazującą, iż średnia liczba ofert składanych w postępowaniach ogółem w 2016 r. wyniosła 2,87, a w 2015 r. 2,90, zaś w postępowaniach na usługi odpowiednio 2,80 i 2,96, można wykazać, że podmioty ekonomii społecznej są skuteczne w uzyskiwaniu zamówień publicznych [Urząd Zamówień Publicznych, 2017, s. 45, 118].

\section{Rysunek 5. Liczba postępowań, w których brały udział PES w latach 2015-2016 i liczba uzyskanych zamówień ( $\mathrm{n}=62$ )}

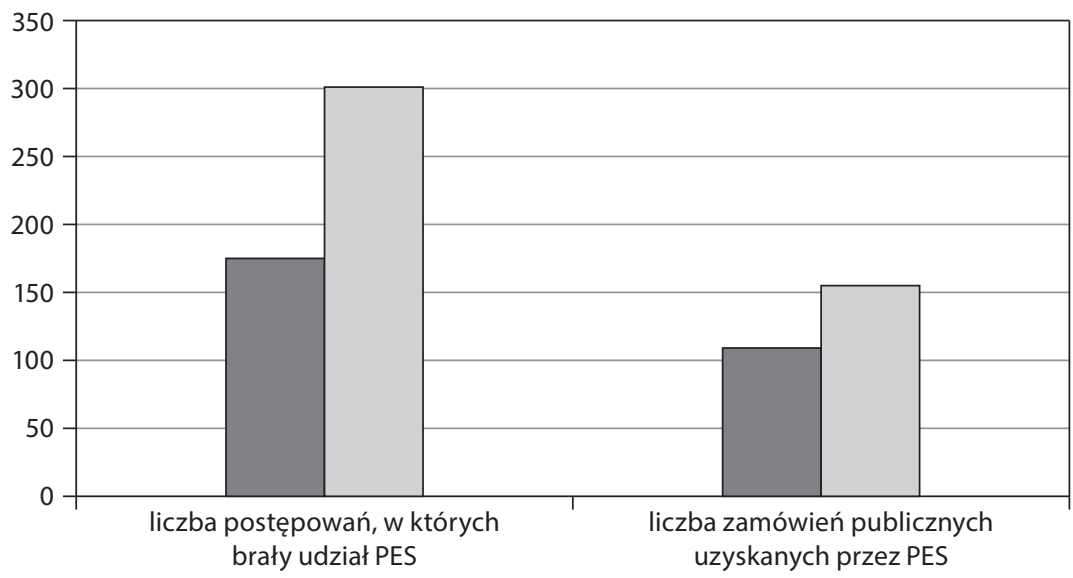

$\square 2015 \square 2016$

Źródło: badania własne.

Podmioty ekonomii społecznej najczęściej starały się o zamówienia publiczne na usługi - tak wskazało aż 90,5\% PES. Tylko kilka podmiotów ubiegało się o uzyskanie zamówień na roboty budowlane, dostawy i inne zamówienia (rys. 6.). Można w tym kontekście wskazać na pewną specyfikę podmiotów ekonomii społecznej i ich obszarów działalności, bowiem w przypadku zamówień publicznych największy rynek stanowią zamówienia na dostawy - w 2016 r. było to 36\% ogólnej kwoty zamówień. Roboty budowlane pochło- 
nęły 34\% wartości, a usługi 30\% [Urząd Zamówień Publicznych, 2017, s. 37]. PES koncentrują się natomiast na usługach, w niewielkim zakresie oferując działania w zakresie dostaw czy robót budowlanych, stąd też biorą udział głównie w postępowaniach na udzielenie zamówień na usługi.

\section{Rysunek 6. Rodzaje zamówień publicznych, o które ubiegały się podmioty ekonomii społecznej $(n=62)$}

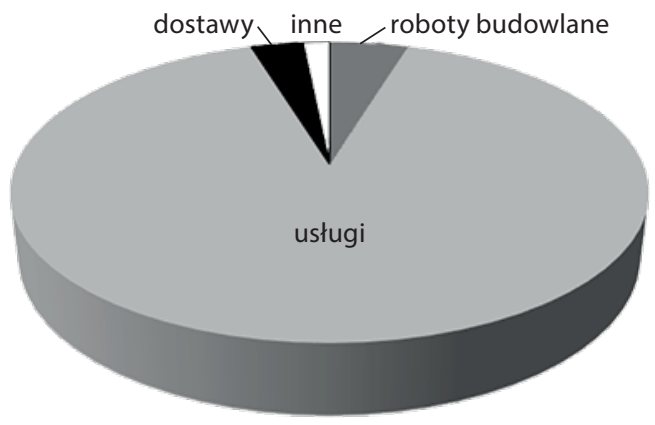

Jeślichodzi o tryby, w których PES ubiegały się o zamówienia to najczęściej wymieniano przetarg nieograniczony $(34,1 \%)$ i zapytania ofertowe (26,4\%). W dużej mierze przyczyną częstotliwości uczestniczenia w takich formach zamówień publicznych jest ich popularność oraz specyfika działalności PES, które koncentrują się na usługach. Te tryby są bezpieczne z punktu widzenia sektora publicznego, bowiem pozwalają na udział większej liczby podmiotów, gwarantując zachowanie konkurencyjności postępowania.

Należy też podkreślić, że zdecydowaną większość zamówień publicznych, o które ubiegały się podmioty ekonomii społecznej, stanowiły te o wartości do 30 tysięcy euro. Wskazało na nie 60 podmiotów, a więc 96,8\%. Na postępowania o wartości powyżej 30 tysięcy euro wskazało tylko 5 PES (8,1\%). Takie duże zamówienia z jednej strony dają szansę na zatrudnienie większej liczby pracowników i szerszą realizację celów, ale z drugiej wymagają odpowiedniego potencjału, którego wiele podmiotów nie posiada.

Rodzaje zamówień, o których uzyskanie starały się PES, tryby ubiegania się o nie i war- tość zamówień nie zależą od formy prawnej PES oraz innych cech charakteryzujących podmioty ekonomii społecznej (wiek, branża, województwo itd.). Udział w konkretnych rodzajach postępowań jest zwykle funkcją wielu zmiennych - z jednej strony zaangażowania PES, z drugiej zaś zamówień ogłaszanych przez podmioty sektora publicznego.

\section{Przyczyny braku udziału PES w postępowaniach o udzielenie zamówienia publicznego}

Jak już wskazano, aż 306 badanych PES, czyli 79,3\% ogółu, nigdy nie uczestniczyło w postępowaniach o udzielenie zamówienia publicznego. Postawić należy w tym kontekście pytanie o przyczyny braku zainteresowania takim sposobem pozyskiwania zleceń w ramach działalności gospodarczej. Odpowiadając na tak sformułowany problem podmioty ekonomii społecznej mogły wskazać dowolną liczbę powodów, co zaowocowało stworzeniem długiej ich listy (rys. 7.). 


\section{Rysunek 7. Przyczyny braku udziału w postępowaniach o udzielenie zamówienia} publicznego $(n=306)$

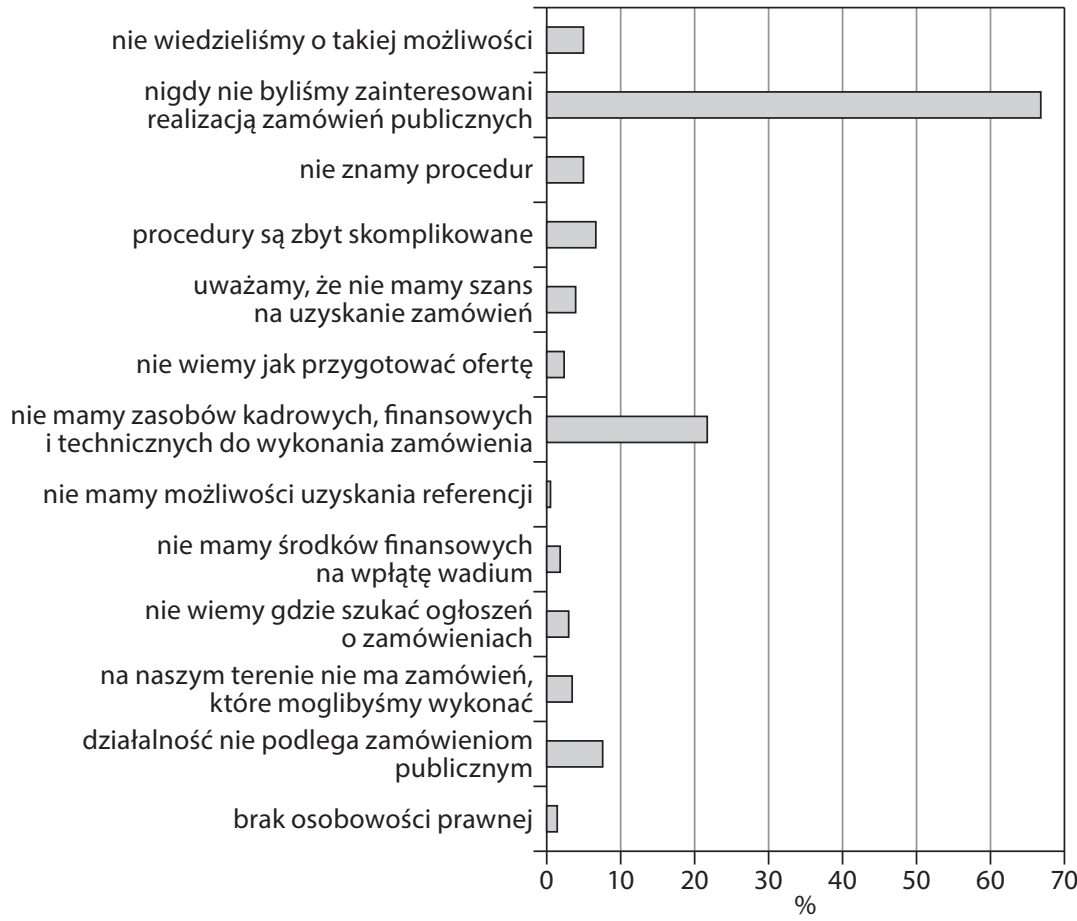

Źródło: badania własne.

Wśród wskazywanych przyczyn braku udziału w zamówieniach jedna była szczególnie często wymieniana - aż 204 podmioty, a więc $66,7 \%$, nigdy nie były zainteresowane realizacją zamówień publicznych. Brak zainteresowania można łączyć z niektórymi innymi, dodatkowymi odpowiedziami udzielanymi przez PES, tj. pozyskiwaniem zleceń w inny sposób, posiadaniem środków finansowych pochodzących z innych źródeł, wąskim zakresem działalności, chęcią zachowania niezależności od podmiotów publicznych, brakiem wiedzy o możliwości uczestniczenia w postępowaniach o udzielenie zamówienia publicznego podmiotów ekonomii społecznej. Świadczy to jednakże o tym, że podmioty ekonomii społecznej nie rozpatrują tej formy pozyskiwania zleceń jako możliwej opcji w swojej działalności.
Przyczyną nieuczestniczenia w zamówieniach publicznych jest również brak zasobów kadrowych, finansowych i technicznych niezbędnych do przygotowania oferty i wykonania zamówienia. Wskazało na nią 21,6\% PES niebiorących udziału w zamówieniach. Szczególne znaczenie ma tutaj niedostatek etatowego personelu oraz brak środków finansowych ograniczających możliwość rozwijania działalności i realizacji szczególnie większych zleceń.

Podmioty wskazywały też, że ich działalność nie podlega zamówieniom publicznym, stąd nie mają szans na udział $w$ tej procedurze - dotyczyło to 7,5\% PES. Dodatkowo 3,3\% podkreślało, że na terenie na którym prowadzą działalność nie ma zamówień, które mogliby pozyskiwać i realizować. Działają więc w takich branżach, w których 
instytucje publiczne nie udzielają zamówień publicznych.

Istotną grupą przyczyn nieuczestniczenia w zamówieniach publicznych jest brak wiedzy i umiejętności dotyczących tego obszaru działalności. Badane podmioty ekonomii społecznej wskazywały, iż nie wiedziały o możliwości udziału w zamówieniach (4,9\%), nie znają procedur $(4,9 \%)$ lub też są one dla nich zbyt skomplikowane $(6,5 \%)$, nie mają szans na uzyskanie zamówień (3,9\%), nie wiedzą, gdzie szukać ogłoszeń (2,9\%), czy nie wiedzą, jak przygotować ofertę (2,3\%). W tym kontekście jako niezwykle istotne jawią się działania wspierające, dzięki którym możliwe jest zapoznanie PES z zasadami udziału w zamówieniach publicznych oraz wsparcie ich w poszukiwaniu zamówień i przygotowaniu ofert. Takie inicjatywy mogą zainteresować podmioty ekonomii społecznej zamówieniami publicznymi i zachęcić do udziału w postępowaniach tych, którzy dotychczas w ogóle nie rozważali takiej opcji.

\section{Czy klauzule społeczne mogą wspierać udział podmiotów ekonomii społecznej w zamówieniach publicznych?}

Podmioty ekonomii społecznej bardzo często nie są konkurencyjne wobec klasycznych podmiotów gospodarczych, co wynika z faktu koncentrowania się na realizacji celów społecznych, m.in. społecznej i zawodowej reintegracji osób zagrożonych marginalizacją, świadczenia nie zawsze ekonomicznie opłacalnych usług społecznych. Stąd również w postępowaniach o udzielenie zamówienia publicznego ich oferty mogą być mniej atrakcyjne. Sektor publiczny ma jednak możliwość wspierania udziału PES w zamówieniach poprzez stosowanie klauzul społecznych, czyli prawnych rozwiązań pozwalających zamawiającym uwzględniać istotne aspekty społeczne w zamówieniach, promować wyrównywanie szans i integrację społeczno- -zawodową osób zagrożonych wykluczeniem. Do funkcjonujących w tym zakresie rozwiązań zaliczyć należy:

- klauzulę zastrzeżoną - pozwalającą na ograniczenie możliwości uczestniczenia w postępowaniach o udzielenie zamówienia publicznego wyłącznie do zakładów pracy chronionej i podmiotów, których działalność obejmuje społeczną i zawodową integrację osób będących członkami grup społecznie marginalizowanych;

- klauzulę zatrudnieniową - pozwalającą na określenie wymogu zatrudnienia przy realizacji zamówienia osób bezrobotnych, młodocianych w celu przygotowania zawodowego, osób niepełnosprawnych oraz innych, o których mowa w ustawie o zatrudnieniu socjalnym;

- klauzulę dotyczącą zatrudniania na umowę o pracę - wymagającą od wykonawcy zamówienia zatrudnienia przy jego realizacji osób na podstawie umowy o pracę (od 28 lipca 2016 r. zatrudnianie na umowę o pracę jest obligatoryjne);

- klauzulę dotyczącą uwzględniania aspektów społecznych jako kryteriów oceny ofert - pozwalającą na uwzględnianie innych niż tylko cena lub koszt kryteriów w ocenie ofert, w tym na premiowanie podmiotów zatrudniających osoby z grup społecznie marginalizowanych;

- klauzulę umożliwiającą ograniczenie podmiotów ubiegających się o udzielenie zamówienia do 30000 euro wyłącznie do spółdzielni socjalnych;

- klauzulę umożliwiającą ograniczenie podmiotów ubiegających się o udzielenie zamówienia do podmiotów ekonomii społecznej przy udzielaniu zamówień w ramach realizacji projektów finansowanych ze środków europejskich [Moroń, 2017].

Klauzule mogą preferować PES poprzez ograniczenie możliwości udziału w postępowaniu tylko do PES lub ich określonych form prawnych (spółdzielni socjalnych) lub też 
premiować podmioty realizujące przy okazji działalności gospodarczej cele społecznej lub zawodowej reintegracji osób z grup zagrożonych marginalizacją.

Z przeprowadzonych badań wynika, że spośród 62 PES, które w latach 2015-2016 brały udział w postępowaniach, 34 brały udział w postępowaniach z klauzulami, zaś 28 wyłącznie w postępowaniach, w których nie stosowano klauzul. Podmioty wzięły udział łącznie w 475 postępowaniach, w tym w 193 postępowaniach, w których zastosowano klauzule społeczne. Można więc wykazać, że 40,6\% postępowań, w których brały udział PES, zawierało klauzule społeczne. Z pewnością wiele podmiotów ekonomii społecznej poszukuje postępowań z klauzulami i bierze w nich udział w związku z tworzonymi w ten sposób preferencjami dla PES i większymi szansami na uzyskanie zamówień. Klauzule społeczne mogą więc stanowić dla podmiotów ekonomii społecznej czynnik wspierający w uzyskiwaniu zamówień publicznych, rekompensujący realizację przez PES misji społecznej, szczególnie w zakresie zatrudnienia osób z kategorii zagrożonych marginalizacją.

Podmioty ekonomii społecznej zauważają znaczenie klauzul społecznych i w przeważającej większości uznają je za rozwiązania korzystne dla PES (rys. 8.). Pokazuje to, że zwiększenie zakresu stosowania klauzul społecznych sprzyjać może zaangażowaniu podmiotów ekonomii społecznej w udział w zamówieniach publicznych.

\section{Rysunek 8. Liczba postępowań, w których brały udział PES w latach 2015-2016 i liczba uzyskanych zamówień ( $\mathrm{n}=62)$}

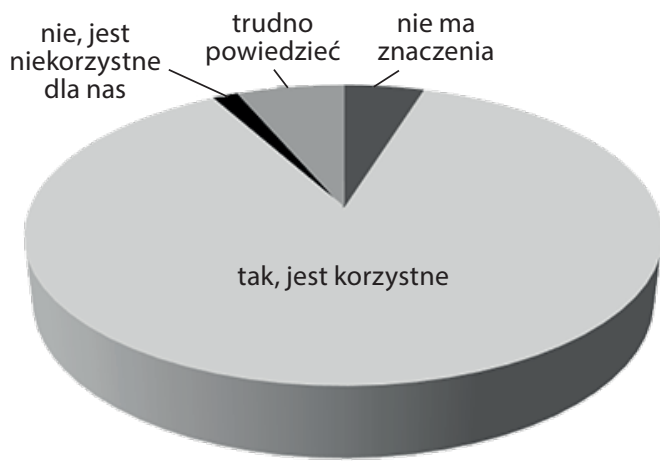

Źródło: badania własne

\section{Podsumowanie}

Działalność gospodarcza podmiotów ekonomii społecznej, szczególnie przedsiębiorstw społecznych, jest istotnym aspektem ich funkcjonowania. Realizacja zadań ekonomicznych, przejawiająca się m.in. w prowadzeniu działalności gospodarczej, dążącej do wypracowania zysku, czyni PES podobnymi do prywatnych przedsiębiorstw. Jednocześnie specyfiką ich funkcjonowania, w odróżnieniu od klasycz- nych przedsiębiorstw rynkowych, jest łączenie celów społecznych i ekonomicznych. To właśnie reinwestowanie zysku w priorytety społeczne wskazuje na odmienność PES i ich ważną rolę nie tylko w powiększaniu PKB i rozwoju gospodarczym, ale także w rozwoju społecznym.

Podobnie jak klasyczne przedsiębiorstwa, podmioty ekonomii społecznej w swojej działalności gospodarczej pozyskiwać mogą zlecenia z różnych źródeł, w tym od sek- 
tora publicznego. Udział w postępowaniach o udzielenie zamówienia publicznego ogłaszanych przez instytucje publiczne może stanowić jeden z obszarów aktywnej walki o nie. Przeprowadzone badanie empiryczne pozwoliło na pozytywną weryfikację hipotezy zakładającej, że większość podmiotów ekonomii społecznej nie jest zainteresowanych zamówieniami publicznymi i nie bierze udziału w postępowaniach o udzielenie zamówienia publicznego. Jedynie co piąty z badanych PES próbował pozyskiwać zlecenia w ten sposób, a podmioty bardzo aktywne w sferze zamówień, biorące udział w wielu postępowaniach i uzyskujące większą liczbę zleceń, stanowiły niewielką część sektora ekonomii społecznej. Przyczyn tej sytuacji można szukać w specyfice funkcjonowania PES, szczególnie stowarzyszeń i fundacji, dla których działalność gospodarcza ma charakter uzupełniający realizację celów statutowych, ich niewielkim potencjale finansowym i zatrudnieniowym, braku wiedzy o zamówieniach publicznych i umiejętności w zakresie udziału w nich, a także działalności w branżach, które nie należą do uwzględnianych w zamówieniach publicznych. Jednocześnie podmioty, które biorą udział w zamówieniach są skuteczne w uzyskiwaniu zleceń i mogą dzięki temu realizować cele społeczne, w tym zadania z zakresu społecznej i zawodowej reintegracji osób zagrożonych wykluczeniem.

Pozytywne doświadczenia udziału w postępowaniach o udzielenie zamówienia publicznego wskazują, że zlecenia publiczne mogą stanowić dla PES ważny sposób pozyskiwania zamówień, a co za tym idzie realizacji celów ekonomicznych. W tym celu konieczne jest wieloaspektowe wsparcie podmiotów ekonomii społecznej w udziale w postępowaniach o udzielenie zamówienia, szczególnie tych, które potencjalnie byłyby zainteresowane taką formą uzyskiwania zleceń, ale napotykają bariery utrudniające im takie działania. Udział podmiotów ekonomii społecznej w za- mówieniach publicznych wesprzeć mogą następujące działania:

- wsparcie doradcze i szkoleniowe dla PES dotyczące korzyści z uzyskiwania zleceń w formie zamówień publicznych, zwiększania wiedzy i umiejętności w zakresie poszukiwania zamówień publicznych i udziału w procesie postępowania o udzielenie zamówienia;

- wsparcie doradcze PES w zakresie realizacji i rozliczania zamówień publicznych;

- upowszechnienie informacji o klauzulach społecznych jako formach wsparcia podmiotów ekonomii społecznej;

- wsparcie doradcze i szkoleniowe dla instytucji publicznych, szczególnie samorządów lokalnych, w zakresie stosowania klauzul społecznych w zamówieniach publicznych jako form wsparcia podmiotów ekonomii społecznej;

- wprowadzanie do prawa nowych rozwiązań (klauzul społecznych) preferujących PES w zamówieniach publicznych. W tym kontekście wartościowe byłoby wprowadzenie możliwości stosowania klauzuli umożliwiającej ograniczenie podmiotów ubiegających się o udzielenie zamówienia do podmiotów ekonomii społecznej - jak to ma aktualnie miejsce przy udzielaniu zamówień w ramach realizacji projektów finansowanych ze środków europejskich - przy udzielaniu zamówień finansowych ze środków jednostek samorządu terytorialnego.

Podmioty ekonomii społecznej wciąż stanowią niewielki, ale ważny sektor łączący realizację celów gospodarczych ze społecznymi. Ze względu na społeczną misję są sojusznikiem instytucji publicznych i powinny uzyskiwać wsparcie w pozyskiwaniu i realizacji zleceń publicznych. Zamówienia publiczne stanowią więc istotny obszar kooperacji na linii sektor publiczny - ekonomia społeczna, a zwiększenie udziału PES w ich pozyskiwaniu i realizacji z pewnością przyniesie wielostronne korzyści. 


\section{Literatura}

Batko R., Bogacz-Wojtanowska E. (2015). „Przedsiębiorstwa społeczne - poszukiwanie tożsamości pomiędzy celami ekonomicznymi a społecznymi", Problemy Zarządzania, vol. 13, nr 4, s. 195-206.

Chomątowska M. (2014). "Możliwości wsparcia publicznego dla podmiotów ekonomii społecznej realizujących zadania publiczne", Ekonomia Spoteczna, nr 2, s. 21-28.

Minister Rozwoju i Finansów (2016). Wytyczne w zakresie realizacji przedsięwzięć $w$ obszarze włączenia społecznego i zwalczania ubóstwa z wykorzystaniem środków Europejskiego Funduszu Społecznego i Europejskiego Funduszu Rozwoju Regionalnego na lata 2014-2020, Warszawa: Minister Rozwoju i Finansów, https://www.funduszeeuropejskie.gov.pl/media/ 27996/wytyczne_CT9_24.pdf.

Moroń D. (2017). Podmioty ekonomii społecznej a zamówienia publiczne. Diagnoza dla województw: dolnoślaskiego, lubuskiego, opolskiego i wielkopolskiego, Wałbrzych: Fundacja "Merkury".

MPiPS (2014). Krajowy Program Rozwoju Ekonomii Społecznej, Warszawa: Ministerstwo Pracy i Polityki Społecznej.

Pacut A. (2015). „Rozwój przedsiębiorczości społecznej - istota i kierunki analizy", Ekonomia Społeczna, nr 1, s. 7-20.

Schimanek T. (2015). „Finansowanie przedsiębiorstw społecznych w Polsce", Ekonomia Społeczna, nr 2, s. 7-20.

Urząd Zamówień Publicznych (2017). Sprawozdanie Prezesa Urzędu Zamówień Publicznych o funkcjonowaniu systemu zamówień publicznych w 2016 r. Warszawa: Urząd Zamówień Publicznych.

Zboroń H. (2015). „Ekonomia społeczna a ekonomia rynku - alternatywa czy dopełnienie?", Studia Oeconomica Posnaniensia, vol. 3, nr 7, s. 7-19.

\section{Participation of social economy entities in public procurement}

Summary: The social economy entities most often run a business activity, thus acquiring funds that can be allocated to the current functioning of the enterprise and the implementation of social objectives. The aim of the article is to analyze the participation of social economy entities in public procurement proceedings as one of the forms of obtaining orders within the framework of business activity. It presents the results of empirical research in this area. The article uses the desk research method and the statistical method in terms of quantity. The conducted research showed that the majority of social economy entities are not interested in public contracts and does not participate in public procurement procedures. At the same time, some social economy entities successfully use such activities, which allows to indicate that public procurement can be an attractive form of obtaining orders.

Keywords: social economy entities, economic activity, public procurement, social clause.

\section{Prawa autorskie i licencja / Copyright and License}

Artykuł opublikowano na licencji Creative Commons

Uznanie autorstwa - Użycie niekomercyjne - Bez utworów zależnych 3.0 Polska

http://creativecommons.org/licenses/by-nc-nd/3.0/pl/

This article is published under the terms of the Creative Commons

Attribution - NonCommercial - NoDerivs (CC BY-NCND 3.0) License

http://creativecommons.org/licenses/by-nc-nd/3.0/ 